\title{
EVALUASI PENGGUNAAN OBAT ANTIHIPERTENSI PADA PASIEN GERIATRI RAWAT JALAN DI RSUD DR. A. DADI TJOKRODIPO
}

\author{
DRUGS USE EVALUATION OF ANTIHYPERTENSIVE \\ THERAPY IN OUTPATIENT GERIATRIC PATIENTS \\ AT DR. A. DADI TJOKRODIPO HOSPITAL \\ Lilik Koernia Wahidah ${ }^{1}$, Novita Tri Wahyuni ${ }^{2)}$, Hijrah $^{2)}$, Miftahul Choiriah ${ }^{3)}$ \\ Program Studi Farmasi, Universitas Tulang Bawang Lampung \\ Email: lilik.koernia82@gmail.com \\ 081369060708
}

\begin{abstract}
Hypertension is a condition in which systolic blood pressure $\geq 140 \mathrm{mmHg}$ or diastolic blood pressure $\geq 90 \mathrm{mmHg}$. Hypertension is often found in geriatrics that can affect the onslence of heart disease and blood vessels. Increased cases of hypertension, the rational use of drugs by hypertensive patients is one of the important elements in achieving health quality. The purpose of this study is to find out the harsh use of antihypertensive drugs in outpatient geriatric patients at Dr. A. Dadi Tjokrodipo Hospital bandar Lampung. This type of research is non experimental with a descriptive design using retrospective data with purposive sampling methods. The results of the study were based on the pattern of use of antihypertensive with the ATC/DDD method in hypertension patients in Dr. A. Dadi Tjokrodipo Bandar Lampung city is 5331,03 DDD/1000 KPRJ, there are nine types of antihypertensive used, namely amlodipine, lisinopril, candesartan, irbesartan, furosemide, spironolactone, ramipril, bisoprolol and captopril. Antihypertensive in the drug uses segment $90 \%$, namely amlodipine $44.37 \%$, lisinopril $16.88 \%$, candesartan $15.46 \%$ and irbesartan $13.65 \%$. The study was based on $100 \%$ patient accuracy criteria, $100 \%$ indication accuracy, $89.3 \%$ drug accuracy and $92 \%$ dose accuracy. The conclusion of this study, the pattern of use of antihypertensive widely used is amlodipine amounting to 2365.52 DDD/1000 KPRJ, antihypertensive that enters the drug uses segment $90 \%$ namely amlodipine, lisinopril, candesartan and irbesartan.
\end{abstract}

Keywords: Antihypertensive, Geriatrics, Outpatient, Drug Use

\begin{abstract}
Abstrak
Hipertensi merupakan kondisi di mana tekanan darah sistolik $\geq 140 \mathrm{mmHg}$ atau tekanan darah diastolik $\geq 90 \mathrm{mmHg}$. Hipertensi sering ditemukan pada geriatri yang dapat mempengaruhi terjadinya penyakit jantung dan pembuluh darah. Peningkatan kasus hipertensi maka penggunaan obat yang rasional oleh pasien hipertensi merupakan salah satu elemen penting dalam tercapainya kualitas kesehatan. Tujuan penelitian ini untuk mengetahui kerasionalan penggunaan obat antihipertensi pada pasien geriatri rawat jalan di RSUD Dr. A. Dadi Tjokrodipo Kota Bandar Lampung. Jenis penelitian ini adalah non eksperimental dengan rancangan deskriptif menggunakan data retrospektif dengan metode purposive sampling. Hasil penelitian berdasarkan pola penggunaan antihipertensi dengan metode ATC/DDD pada pasien hipertensi di RSUD Dr. A. Dadi Tjokrodipo Kota Bandar Lampung yaitu 5331,03 DDD/1000 KPRJ, terdapat sembilan jenis antihipertensi yang digunakan, yaitu amlodipine, lisinopril, candesartan, irbesartan, furosemide, spironolactone, ramipril, bisoprolol dan captopril. Antihipertensi yang masuk dalam drug uses segmen $90 \%$, yaitu amlodipine $44,37 \%$, lisinopril $16,88 \%$, candesartan $15,46 \%$ dan irbesartan $13,65 \%$.
\end{abstract}


Penelitian kerasionalan berdasarkan kriteria ketepatan pasien 100\%, ketepatan indikasi $100 \%$, ketepatan obat $89,3 \%$ dan ketepatan dosis $92 \%$. Kesimpulan dari penelitian ini, pola penggunaan antihipertensi yang banyak digunakan yaitu amlodipine sebesar 2365,52 DDD/1000 KPRJ, antihipertensi yang masuk dalam drug uses segmen $90 \%$ yaitu amlodipine, lisinopril, candesartan dan irbesartan.

Kata Kunci: Hipertensi, Geriatri, Rawat Jalan, Penggunaan Obat

\section{PENDAHULUAN}

Hipertensi merupakan masalah kesehatan besar di seluruh dunia, selain tingginya prevalensi, hipertensi juga berhubungan dengan peningkatan risiko penyakit kardiovaskular $^{(1)}$. Hipertensi menjadi ancaman kesehatan masyarakat karena potensinya yang mampu mengakibatkan kondisi komplikasi seperti stroke, penyakit jantung koroner dan gagal ginjal ${ }^{(2)}$.

Berdasarkan hasil Riset Kesehatan Dasar (Riskesdas) Tahun 2018, prevalensi hipertensi di Indonesia sebesar $34,1 \%$ dan di Provinsi Lampung sendiri memiliki prevalensi sekitar 29,9\%. Hasil Rikesdas menunjukkan bahwa prevalensi hipertensi juga meningkat seiring dengan peningkatan umur, semakin tinggi umur seseorang maka semakin berisiko untuk mengidap hipertensi ${ }^{(3)}$. Kasus hipertensi pada pasien geriatri mempunyai risiko lebih tinggi yaitu pada usia 60-74 tahun sebesar $65,7 \%^{(4)}$. Masalah kesehatan pada geriatri berawal dari kemunduran sel-sel tubuh, sehingga fungsi dan daya tahan tubuh menurun serta faktor risiko terhadap penyakit pun meningkat ${ }^{(5)}$.

Seiring dengan peningkatan kasus hipertensi maka penggunaan obat yang rasional oleh pasien hipertensi merupakan salah satu elemen penting dalam tercapainya kualitas kesehatan ${ }^{(6)}$. Penderita hipertensi yang tidak diterapi dapat menyebabkan terjadinya komplikasi yang dapat memperburuk keadaan penderita. Pengobatan yang rasional terdiri atas ketepatan terapi yang dipengaruhi oleh proses diagnosis, pemilihan terapi, pemberian terapi serta evaluasi terapi ${ }^{(7)}$. Evaluasi penggunaan obat antihipertensi bertujuan untuk menjamin penggunaan obat yang rasional pada penderita hipertensi.

Evaluasi penggunaan antihipertensi dapat menggunakan metode anatomical therapeutic chemical (ATC)/ defined daily doses (DDD). Penggunaan metode ATC/DDD dapat juga diintegrasikan dengan drug uses 90\% (DU 90\%). Metode DU $90 \%$ dapat digunakan untuk mengidentifikasi segmen penggunaan terbanyak dalam studi penggunaan obat di suatu populasi. Metode ini direkomendasikan oleh world health organization (WHO) untuk mengevaluasi penggunaan obat ${ }^{(8)}$.

RSUD Dr. A. Dadi Tjokrodipo adalah rumah sakit umum daerah milik pemerintah dan merupakan salah satu rumah sakit tipe $C$ yang terletak di wilayah Kota Bandar Lampung. Hipertensi merupakan penyakit yang masuk ke dalam sepuluh besar penyakit di RSUD Dr. A. Dadi Tjokrodipo.

Berdasarkan tingkat penggunaan obat antihipertensi pada pasien geriatri membuat peneliti tertarik untuk melakukan penelitian tentang evaluasi penggunaan obat antihipertensi pada pasien geriatri rawat jalan di RSUD Dr. A. Dadi Tjokrodipo kota Bandar Lampung.

\section{METODE PENELITIAN}

Penelitian yang dilakukan adalah penelitian observasional dengan jenis deskriptif, penggumpulan data dilakukan secara retrospektif dengan menggunakan data rekam medis pasien geriatri yang menderita hipertensi di RSUD Dr. A. Dadi Tjokrodipokota Kota Bandar Lampung pada periode Juli-Desember 2019. Teknik pengambilan sampel dalam penelitian ini menggunakan metode purposive 


\section{JFL \\ Jurnal Farmasi Lampung}

sampling. Data yang diperoleh diolah dengan menggunakan metode ATC/DDD dan DU 90\%, kemudian dilakukan evaluasi ketepatan berdasarkan tepat pasien, tepat indikasi, tepat obat dan tepat dosis.

\section{Lokasi dan Waktu Penelitian} Penelitian ini dilakukan pada bulan Agustus 2020 di RSUD Dr. A. Dadi Tjokrodipo Kota Bandar Lampung.

\section{Populasi dan Sampel}

Populasi dalam penelitian ini adalah pasien geriatri yang menderita hipertensi rawat jalan di RSUD Dr. A. Dadi Tjokrodipo Kota Bandar Lampung pada periode Juli-Desember 2019. Penentuan sampel menggunakan rumus slovin:

$$
\mathrm{n}=\frac{\mathrm{N}}{1+\mathrm{N}(\mathrm{d})^{2}}
$$

Keterangan:

$\mathrm{n}=$ Jumlah sampel

$\mathrm{N}=$ Jumlah populasi

$d=$ Tingkat kepercayaan $(d=0,05)$

Setelah dilakukan perhitungan menggunakan rumus slovin didapatkan sampel berjumlah 75 pasien dari jumlah populasi sebanyak 290 pasien.

3. Instrumen dan Pengolahan Data Intrumen dalam penelitian ini menggunakan data rekam medis pasien geriatri yang menderita hipertensi. Data yang telah dikumpulkan dilakukanpengolahan data dengan tahapan sebagai berikut:
a. Editing, dilakukan dengan memeriksa ulang lembar pengambilan data (LPD) yang diperoleh dari rekam medis rawat jalan di RSUD Dr. A. Dadi Tjokrodipo Kota Bandar Lampung.

b. Coding, dilakukan untuk mengelompokan data-data yang diperoleh dari rekam medis rawat jalan di RSUD Dr. A. Dadi Tjokrodipo Kota Bandar Lampung.

c. Entry data, yaitu penggunaan antihipertensi akan diukur dengan metode DDD sesuai klasifikasi ATC yang telah direkomendasikan oleh WHO.

d. Cleaning, dilakukan untuk memeriksa data-data yang telah dimasukan.

\section{HASIL DAN PEMBAHASAN}

Berdasarkan rekapitulasi data yang telah dilakukan di RSUD Dr. A. Dadi Tjorodipo Kota Bandar Lampung pada periode JuliDesember 2019 didapatkan data sebagai berikut:

\section{Karakteristik Pasien Hipertensi}

Penelitian ini didapatkan 75 sampel pada pasien hipertensi geriatri di RSUD Dr. A. Dadi Tjokrodipo Kota Bandar Lampung pada peroide Juli-Desember 2019 yang dikelompokkan berdasarkan karakteristik data. Adapun karakteristik data dapat dilihat pada tabel 1 berikut ini:

Tabel 1. Karakteristik pasien Hipertensi

\begin{tabular}{|c|c|c|}
\hline Karakteristik & $\begin{array}{c}\text { Jumlah } \\
\text { Pasien } \\
\mathrm{n}=75\end{array}$ & $\begin{array}{c}\text { Persentase } \\
\%\end{array}$ \\
\hline \multicolumn{3}{|l|}{ Jenis Kelamin } \\
\hline Laki- Laki & 31 & $41 \%$ \\
\hline Perempuan & 44 & $59 \%$ \\
\hline \multicolumn{3}{|l|}{ Umur } \\
\hline $60-74$ tahun & 60 & $80 \%$ \\
\hline 75 - 90 tahun & 15 & $20 \%$ \\
\hline \multicolumn{3}{|l|}{ Derajat Hipertensi } \\
\hline Hipertensi stage 1 & 25 & $33 \%$ \\
\hline Hipertensi stage 2 & 50 & $67 \%$ \\
\hline \multicolumn{3}{|l|}{$\begin{array}{l}\text { Frekuensi Penderita } \\
\text { Hipertensi }\end{array}$} \\
\hline Tanpa Komplikasi & 25 & $33,3 \%$ \\
\hline Dengan Komplikasi & 50 & $66,7 \%$ \\
\hline
\end{tabular}

Berdasarkan tabel 1 menunjukan karakteristik pasien hipertensi di RSUD Dr. A. Dadi Tjokrodipo Kota Bandar Lampung pada peroide Juli-Desember 2019, dari 75 pasien bahwa jenis kelamin perempuan lebih banyak mengalami hipertensi sebesar $59 \%$ sedangkan pada laki-laki hanya sebesar $41 \%$. Hal ini disebabkan karena pada perempuan yang sudah mengalami menopause kadar esterogen mengalami penurunan, 


\section{JFL \\ Jurnal Farmasi Lampung}

sehingga kadar HDL yang berfungsi melindungi pembuluh darah dari kerusakan juga menurun ${ }^{(9)}$.

Karakteristik pasien berdasarkan umur dari 75 pasien hipertensi geriatri yang paling banyak adalah rentang usia $60-74$ tahun sebesar $80 \%$ dan paling kecil pada rentang usia $75-90$ tahun sebesar $20 \%$. Hal ini disebabkan karena adanya pengkakuan pembuluh darah dan penurunan kelenturan arteri dan mengakibatkan peningkatan tekanan nadi sesuai dengan umur ${ }^{(10)}$.

Karakteristik pasien berdasarkan derajat hipertensi menunjukkan bahwa sebagian besar pasien mengalami hipertensi stage 2 , yaitu sebanyak 50 pasien dan

hipertensi stage 1 sebanyak 25 pasien. Pemilihan obat hipertensi tergantung pada tingginya tekanan darah dan adanya indikasi khusus. Pada kebanyakan pasien, tekanan darah diastolik yang diinginkan akan tercapai apabila tekanan darah sistolik yang diinginkan sudah tercapai ${ }^{(11)}$.

Karakteristik pasien berdasarkan frekuensi penderita hipertensi menunjukkan bahwa sebagian besar pasien geriatri menderita hipertensi dengan adanya komplikasi sebanyak 50 pasien dan sebagian kecil pasien geriatri menderita hipertensi tanpa adanya komplikasi sebanyak 25 pasien. Hal ini karena hipertensi menjadi penyebab utama munculnya berbagai komplikasi pada tubuh khususnya organ target, sehingga tidak hanya hipertensi yang harus ditangani, namun juga kerusakan organ ${ }^{(12)}$.

\section{Distribusi Penggunaan Terapi Obat Antihipertensi}

Berdasarkan hasil penelitian distribusi penggunaan terapi obat antihipertensi pada pasien hipertensi geriatri di RSUD Dr. A. Dadi Tjokrodipo Kota Bandar Lampung dapat dilihat pada tabel 2.
Tabel 2. Distribusi Penggunaan Terapi Obat Antihipertensi

\begin{tabular}{l|l|c|}
\hline Jenis Terapi & $\begin{array}{l}\text { Jumlah } \\
\text { Pasien } \\
\mathbf{n = 7 5}\end{array}$ & $\begin{array}{c}\text { Persen } \\
\text { tase } \\
\%\end{array}$ \\
\hline Monoterapi & 32. & $42,67 \%$ \\
Kombinasi. & 43 & $57,33 \%$ \\
\hline Total & \multicolumn{1}{c}{75} & $100 \%$ \\
\hline
\end{tabular}

Berdasarkan tabel 2 menunjukkan distribusi penggunaan terapi obat antihipertensi terdapat 32 pasien yang mendapatkan monoterapi dan 43 pasien yang mendapatkan terapi kombinasi antihipertensi. Obat antihipertensi yang paling banyak digunakan sebagai monoterapi adalah calcium chanel blockers (CCB). Penggunaan obat antihipertensi golongan $\mathrm{CCB}$ seperti amlodipine banyak digunakan karena merupakan salah satu golongan antihipertensi tahap pertama bagi hipertensi geriatri. Pada terapi kombinasi dengan 2 obat antihipertensi golongan calcium chanel blockers (CCB) dengan angiotensin converting enzyme-inhibitor (ACE-I) adalah yang paling banyak digunakan. Kombinasi antara golongan CCB dengan ACE-I ini telah menunjukkan suatu efek perlindungan ginjal dan meregresi hipertrofi ventrikel kiri ${ }^{(11)}$.

\section{Pola Penggunaan Antihipertensi dengan Metode ATC/DDD}

Berdasarkan hasil penelitian pola penggunaan antihipertensi dengan menggunakan metode ATC/DDD pada pasien hipertensi geriatri di RSUD Dr. A. Dadi Tjokrodipo Kota Bandar Lampung dapat dilihat pada tabel 3 .

Tabel 3. Pola penggunaan antihipertensi dengan metode ATC/DDD

\begin{tabular}{|l|l|c|}
\hline $\begin{array}{l}\text { Antihiperten } \\
\text { si }\end{array}$ & Kode ATC & $\begin{array}{c}\text { DDD/1 } \\
\mathbf{0 0 0} \\
\text { Pasien }\end{array}$ \\
\hline Amlodipine & C08CA01 & 2365,52 \\
\hline Lisinopril & C09AA03 & 900 \\
\hline Candesartan & C09CA06 & 824,14 \\
\hline Irbesartan & C09CA04 & 727,59 \\
\hline Furosemide & C03CA01 & 144,83 \\
\hline $\begin{array}{l}\text { Spironolacto } \\
\text { ne }\end{array}$ & C03DA01 & 127,59 \\
\hline Ramipril & C09AA05 & 103,45 \\
\hline Bisoprolol & C07AB07 & 77,59 \\
\hline Captopril & C09AA01 & 60,34 \\
\hline
\end{tabular}




\section{JFL \\ Jurnal Farmasi Lampung}

Berdasarkan tabel 3 menunjukkan pola penggunaan antihipertensi dengan metode ATC/DDD pada pasien hipertensi di RSUD Dr. A. Dadi Tjokrodipo Kota Bandar Lampung terdapat jenis antihipertensi yang digunakan yaitu amlodipine, lisinopril, captopril, ramipril, candesartan, irbesartan, furosemide, spironolactone dan bisoprolol. Berdasarkan data tersebut diperoleh bahwa amlodipine yang paling banyak digunakan yaitu 2365,52 DDD/1000 KPRJ. Hal ini disebabkan karena golongan CCB sangat efektif pada pasien lansia terutama dengan tekanan darah sistolik meningkat ${ }^{(11)}$.

\section{Pola Konsumsi Antihipertensi Drug Uses Segmen $\mathbf{9 0 \%}$}

Adapun beberapa jenis antihipertensi yang masuk kedalam drug uses segmen $90 \%$ yang dapat dilihat pada tabel 4 .

Tabel 4. Pola konsumsi antihipertensi drug uses segmen $90 \%$

\begin{tabular}{lccc}
\hline \multicolumn{1}{c}{ Antihipertensi } & $\begin{array}{c}\text { DDD/ } \\
\mathbf{1 0 0 0} \\
\text { Pasien }\end{array}$ & \% & $\begin{array}{c}\text { Segmen } \\
\text { DU }\end{array}$ \\
\hline Amlodipine & 2365,5 & 44,37 & \\
Lisinopril & 900 & 16,88 & $90 \%$ \\
Candesartan & 824,14 & 15,46 & \\
Irbesartan & 727,59 & 13,65 & \\
\hline Furosemide & 144,83 & 2,72 & \\
Spironolactone & 127,59 & 2,39 & \\
Ramipril & 103,45 & 1,94 & $10 \%$ \\
Bisoprolol & 77,59 & 1,46 & \\
Captopril & 60,34 & 1,13 & \\
\hline
\end{tabular}

Berdasarkan tabel 4 menunjukan pola konsumsi antibiotik yang masuk ke dalam drug uses segmen $90 \%$ yaitu amlodipine sebesar $44,37 \%$, lisinopril sebesar $16,88 \%$, candesartan sebesar $15,46 \%$ dan irbesartan sebesar $13,65 \%$. Sedangkan antihipertensi yang masuk dalam segmen $10 \%$ yaitu furosemide sebesar $2,72 \%$, spironolactone sebesar $2,39 \%$, ramipril sebesar $1,94 \%$, bisoprolol sebesar $1,46 \%$ dan captopril sebesar 1,13\%. Data yang diperoleh dapat menggambarkan adanya variasi dalam penggunaan antihipertensi dari berbagai jenis serta golongan obat. Ini kemungkinan disebabkan oleh banyaknya penyakit dengan komplikasi, sehingga penggunaan obat antihipertensi juga disesuikan dengan penyakit komplikasinya.

\section{Analisis Ketepatan Penggunaan} Antihipertensi

Penggunaan obat antihipertensi dalam penelitian ini dikaji dengan melihat 4T, yaitu tepat pasien, tepat indikasi, tepat obat dan tepat dosis.

1. Tepat pasien

Berikut merupakan data hasil penelitian berdasarkan ketepatan pasien hipertensi geriatri di RSUD Dr. A. Dadi Tjokrodipo Kota Bandar Lampung periode Juli-Desember 2019 dapat dilihat pada tabel 5 .

Tabel 5. Tepat pasien

\begin{tabular}{ccc}
\hline $\begin{array}{c}\text { Ketepatan } \\
\text { Pasien }\end{array}$ & Diagnosa Jumlah & $\%$ \\
\hline Tepat Pasien Hipertensi & 75 & $100 \%$ \\
\hline $\begin{array}{c}\text { Tidak Tepat Hipertensi } \\
\text { Pasien }\end{array}$ & 0 & $0 \%$ \\
\hline
\end{tabular}

Berdasarkan tabel 5 menunjukan bahwa menunjukan bahwa ketepatan pasien untuk kasus hipertensi di RSUD Dr. A. Dadi Tjokrodipo Kota Bandar Lampung sebesar 100\% memenuhi ketepatan pasien berdasarkan guideline pharmaceutical care untuk penyakit hipertensi tahun 2006. Hal ini karena semua obat yang terdapat di rekam medis pada pasien hipertensi geriatri di RSUD Dr A. Dadi Tjokrodipo Kota Bandar Lampung periode JuliDesember 2019 sesuai dengan kondisi patologi dan fisiologi pasien serta tidak menimbulkan kontraindikasi pada pasien selain itu dokter juga sudah mengerti benar kondisi pasien dan sudah mempertimbangkan pemberian obat yang tepat untuk pasien.

2. Tepat Indikasi

Berikut merupakan data hasil penelitian berdasarkan ketepatan indikasi pasien hipertensi geriatri di RSUD Dr. A. Dadi Tjokrodipo Kota Bandar Lampung 
periode Juli-Desember 2019 dapat dilihat pada tabel 6 .

Tabel 6. Tepat indikasi

\begin{tabular}{cccc}
\hline $\begin{array}{c}\text { Ketepatan } \\
\text { Indikasi }\end{array}$ & Diagnosa & Jumlah & $\%$ \\
\hline Tepat Indikasi & Hipertensi & 75 & $100 \%$ \\
\hline $\begin{array}{c}\text { Tidak Tepat } \\
\text { Indikasi }\end{array}$ & Hipertensi & 0 & $0 \%$ \\
\hline
\end{tabular}

Berdasarkan tabel 6 menunjukan bahwa ketepatan indikasi untuk kasus hipertensi di RSUD Dr. A. Dadi Tjokrodipo Kota Bandar Lampung sebesar 100\% memenuhi ketepatan indikasi berdasarkan guideline pharmaceutical care untuk penyakit hipertensi tahun 2006. Hal ini disebabkan karena dari semua data yang ada, menunjukkan bahwa tekanan darah lebih dari 140/90 $\mathrm{mmHg}$ pada pasien geriatri usia $65-\geq$ 90 tahun. Dikatakan tepat indikasi apabila pemberian obat sesuai dengan gejala yang dirasakan pasien dan diagnosis yang telah ditegakkan serta telah terbukti manfaat terapinya. Apabila suatu obat diberikan tanpa ada indikasi yang sesuai maka gejala serta penyakit yang diderita pasien tidak akan hilang karena suatu obat memiliki spektrum terapi yang spesifik dan berbeda-beda ${ }^{(13)}$.

3. Tepat Obat

Berikut merupakan data hasil penelitian berdasarkan ketepatan obat pasien hipertensi geriatri di RSUD Dr.

A. Dadi Tjokrodipo Kota Bandar Lampung periode Juli-Desember 2019 dapat dilihat pada tabel 7 .

Tabel 7. Tepat obat

\begin{tabular}{|c|c|c|}
\hline \multirow{2}{*}{ Hipertensi } & \multicolumn{2}{|c|}{ Jumlah (N= 75) } \\
\hline & Tepat & Tidak Tepat \\
\hline Tanpa Komplikasi & 25 & 0 \\
\hline \multicolumn{3}{|l|}{ Dengan Komplikasi: } \\
\hline DM Tipe 2 & 27 & 7 \\
\hline GGK & 8 & 1 \\
\hline Stroke & 7 & 0 \\
\hline Total & 67 & 8 \\
\hline
\end{tabular}

Berdasarkan tabel 7 menunjukkan bahwa dari 75 pasien didapatkan ketepatan obat pada pasien hipertensi sebanyak 67 pasien dinilai tepat obat dan 8 pasien dinilai tidak tepat obat. Adanya ketidaktepatan obat dalam penelitian ini terjadi dikarenakan adanya kombinasi yang tidak tepat dan pemilihan variasi terapi yang tidak sesuai dengan literatur yang digunakan yaitu JNC VII. Ketidaktepatan obat terdapat pada pasien hipertensi dengan komplikasi diabetes mellitus tipe 2 menerima terapi satu macam obat. Dalam JNC VII disebutkan bahwa pemberian obat pada pasien hipertensi dengan penyakit diabetes mellitus diberikan kombinasi dua atau lebih obat untuk mencapai target kurang dari $130 / 80 \mathrm{mmHg}$, sehingga jika terdapat pasien hipertensi dengan komplikasi hanya mendapatkan satu jenis obat maka dinilai tidak tepat obat. Ketidaktepatan lainnya terjadi karena adanya kombinasi antara golongan CCB (amlodipine) dengan golongan ARB (irbesartan) pada hipertensi dengan penyakit gagal ginjal kronis. Dalam JNC VII disebutkan bahwa pemberian obat pada hipertensi dengan penyakit gagal ginjal kronis diberikan golongan obat ACE-I atau ARB yang mempunyai efek melindungi ginjal ${ }^{(11)}$.

\section{Tepat Dosis}

Berikut merupakan data hasil penelitian berdasarkan ketepatan dosis pada pasien hipertensi geriatri di RSUD Dr.

A. Dadi Tjokrodipo Kota Bandar Lampung periode Juli-Desember 2019 dapat dilihat pada tabel 8 .

Tabel 8. Tepat dosis

\begin{tabular}{cccc}
\hline Tepat Dosis & Diagnosa & Jumlah & $\%$ \\
\hline Tepat & & 69 & $92 \%$ \\
& Hipertensi & & \\
Tidak Tepat & & 6 & $8 \%$ \\
\hline
\end{tabular}

Berdasarkan tabel 8 menunjukan bahwa ketepatan dosis untuk pasien hipertensi sebanyak 69 pasien dinilai 


\section{Jurnal Farmasi Lampung}

tepat dosis dan 6 pasien dinilai tidak tepat dosis. Ketepatan dosis disebabkan karena kesesuaian dosis dan obat yang diberikan berdasarkan acuan pharmaceutical care untuk penyakit hipertensi tahun 2006. Sedangkan ketidaktepatan dosis disebabkan karena kurangnya dosis yang diberikan. Pemberian dosis yang sesuai dengan dosis standar sangatlah penting untuk keberhasilan terapi pasien hipertensi. Apabila dosis yang diberikan terlalu rendah atau di bawah rentang terapi, maka efek terapi yang diinginkan karena tidak akan tercapai. Oleh karena itu, dosis yang tepat mewujudkan keberhasilan terapi pada pasien $^{(14)}$.

Dari hasil penelitian ditempat yang sama, Ketepatan penggunaan antibiotik dengan kriteria 4T berdasarkan acuan standar Phamrmaceutical Care untuk Infeksi Saluran Pernafasan tahun 2005 dan British National Formulation 2011-2012 untuk kasus pneumonia pediatri di instalasi rawat inap RSUD Dr. A. Dadi Tjokrodipo periode tahun 2019 diperoleh ketepatan pasien sebanyak $100 \%$, ketepatan indikasi sebanyak $100 \%$, ketepatan dosis sebanyak 57,4 \% dan ketepatan interval waktu pemberian sebanyak $100 \% .{ }^{(15)}$

\section{KESIMPULAN DAN SARAN}

\section{KESIMPULAN}

Berdasarkan hasil dari penelitian ini, diperoleh kesimpulan sebagai berikut:

1. Karakteristik pada pasien hipertensi diperoleh bahwa pasien hipertensi lebih banyak di derita oleh pasien berjenis kelamin perempuan (59\%). Karakteristik berdasarkan umur diperoleh bahwa pasien hipertensi lebih banyak diderita pada rentang umur 60 74 tahun $(80 \%)$.

2. Berdasarkan derajat hipertensi diperoleh bahwa sebagian besar pasien mengalami hipertensi stage 2
(67\%).
Berdasarkan
frekuensi

penderita

hipertensi

yang paling banyak diderita adalah hipertensi dengan komplikasi $(66,7 \%)$. Berdasarkan distribusi penggunaan terapi obat antihipertensi yang paling banyak adalah terapi kombinasi dengan 43 pasien $(57 \%)$.

3. Pola penggunaan antihipertensi dengan metode ATC/DDD pada pasien hipertensi terdapat jenis antihipertensi yang digunakan yaitu amlodipine, lisinopril, captopril, ramipril, candesartan, irbesartan, furosemide, spironolactone dan bisoprolol. Berdasarkan data tersebut diperoleh bahwa amlodipine yang paling banyak 
digunakan yaitu 2365,52 DDD/1000 KPRJ.

4. Pola konsumsi antihipertensi pada pasien hipertensi di RSUD Dr. A. Dadi Tjokrodipo Kota Bandar Lampung yang masuk dalam drug uses segmen $90 \%$ yaitu amlodipine sebesar $44,37 \%$, lisinopril 16,88\%, candesartan $15,46 \%$ dan irbesartan $13,65 \%$.

5. Ketepatan penggunaan obat antihipertensi pada pasien hipertensi berdasarkan pharmaceutical care untuk penyakit hipertensi tahun 2006 dan guideline JNC VII meliputi tepat pasien dan tepat indikasi sebesar $100 \%$, tepat obat $89,3 \%$ dan tepat dosis $92 \%$.

\section{SARAN}

Perlu dilakukan penelitian penggunaan obat pada pasien hipertensi geriatri lebih lanjut dengan prospektif untuk mengamati secara langsung perkembangan terapi pasien, monitoring efek samping dan interaksi obat.

\section{UCAPAN TERIMAKASIH}

Terima kasih kepada para dosen, pihak kampus Universitas tulang Bawang Lampung serta Rumah Sakit Umum Daerah Dr. A. Dadi Tjokrodipo Kota Bandar Lampung yang sudah membantu dalam menyelesaikan penelitian ini.

\section{DAFTAR PUSTAKA}

1. Alifariki, La Ode, dkk. 2019. Epidemiologi Hipertensi. Jogyakarta: PT Leutika Nouvalitera. p. 5.

2. Pikir, S. Budi, M. Aminuddin, Agus Subagjo, dkk. 2015. Hipertensi Manajemen Komprehensif. Surabaya: Airlangga University Press. p. 1-55, 45-55, 75-86.

3. Kementerian Kesehatan Republik Indonesia (Kemenkes RI). 2019. Pusat data dan Informasi kementerian Kesehatan RI. Jakarta: Kementerian Kesehatan RI.

4. Dalyoko, DAP., Y. Kusumawati dan Ambarwati. 2011. Faktor-faktor yang
Berhubungan dengan Kontrol Hipertensi pada Lansia di Pos Pelayanan Terpadu Wilayah Kerja Puskesmas Mojosongo Boyolali. Jurnal Kesehatan, 4(1), 201-214.

5. Sari, R. P., Ledia Restipa \& M. Y. Putri. 2017. Pengaruh Pemberian Jus Semangka Terhadap Penurunan Tekanan Darah Pada Lansia Penderita Hipertensi di Wilayah Kerja Puskesmas Lubuk Buaya Padang. Jurnal IImu Kesehatan, 1(1), 79-86.

6. Ahadiah, Nida, H. E. Suhardiana \& N. Handayani. 2019. Evaluasi Kesesuaian Obat dan Dosis Antihipertensi di Instalansi Rawat Jalan Rumah Sakit "X" Tasikmalaya. Media Informasi, 15(2), 129-137.

7. Khotimah, S. E. Y. N, L. Musnelina. 2016. Evaluasi Penggunaan Obat antihipertensi Pada Pasien Hipertensi Primer Usia 45 Tahun di Instalasi Rawat Jalan RSUD Kota Depok. Sainstech Farma, 9(1), 30-34.

8. Destiani, Dika P, Rina S., dkk. 2015. Evaluasi Penggunaan Obat Antihipertensi Pada Pasien Rawat Jalan di Fasilitas Kesehatan Rawat Jalan Dengan Metode ATC/DDD. Farmaka, 14(2), 19-25.

9. Sari, Yeni Kartika dan E. R. Susanti. 2016. Hubungan Jenis Kelamin Dengan Kejadian Hipertensi Pada Lansia di Puskesmas Nglegok Kabupaten Blitar. Jurnal Ners dan Kebidanan, 3(3), 262265.

10. Rosari, Felicya HS. 2014. Diagnosis And Management Of Hypertension In The Elderly Patient. JK Unila, 3(7), 4651.

11. Departemen Kesehatan RI. 2006. Pharmaceutical Care Untuk Penyakit Hipertensi. Jakarta: Direktorat Bina Farmasi Komunitas dan Klinik. p. 1129.

12. Prasetyorini, Hesty Titis dan Dian Prawesti. 2012. Stres Pada Penyakit Terhadap Kejadian Komplikasi Hipertensi Pada Pasien Hipertensi. Jurnal STIKES. 5(1), 61-70.

13. Adriyana, Novita Diah. 2016. Evaluasi Terapi Penggunaan Obat Antihipertensi Pada Paisen Geriatri di Instalasi Rawat Inap RSUD $d r$. 
Jurnal Farmasi Lampung

Moewardi Surakarta (Naskah

Publikasi). Surakarta: Fakultas

Farmasi Universitas Muhammadiyah Surakarta.

14. Kementerian Kesehatan Republik Indonesia (Kemenkes RI). 2011. Modul Penggunaan Obat Rasional. Jakarta: Kementerian Kesehatan RI. p. 3-12.

15. Wahidah,L.K, Novita TW. MP, 2020, Evaluasi Penggunaan Antibiotik Pneumonia Dengan Metode Atc/Ddd Pada Pasien Pediatri Di Instalasi Rawat Inap Rsud. Dr. A. Dadi Tjokrodipo Bandar Lampung Tahun 2019. Jurnal Farmasi Lampung, 9 (2), 99-108 